\title{
Will World Bank and IMF Lending Lead to HIPC IV? Debt Déjà-Vu All Over Again
}

\section{Benjamin Leo}

\begin{abstract}
Four years ago, the G-7 pushed through an unprecedented initiative forcing the international financial institutions to cancel 100 percent of their outstanding debt claims on the world's poorest countries. Through the Multilateral Debt Relief Initiative (MDRI), these heavily indebted poor countries (HIPCs) stand to receive up to $\$ 60$ billion in debt relief over time. Moreover, the World Bank, African Development Bank, and IMF shareholders approved a new debt sustainability framework to govern future lending decisions and prevent the need for yet another round of systemic debt relief. All parties emerged from these landmark agreements confident that the dragon of unsustainable debt finally had been slain. However, several unsettling trends raise serious questions about the finality of these actions. First, World Bank and AfDB lending disbursement volumes to these very same HIPC countries remain very high, and nearly the same as compared to pre-MDRI. Emergency IMF lending in response to the global economic crisis has compounded the situation. Second, IMF and World Bank growth projections for HIPCs remain overly rosy compared to actual and historical performance. Our new dataset of IMF growth projections suggests a structural optimism of at least one percentage point per year. Third, HIPCs continue to experience significant volatility in country performance measures that has a direct impact on their ability to carry debt sustainably. Taken together, these findings suggest that donor countries should re-examine the issue of debt sustainability in low-income countries and the system for determining the appropriate grant/loan mix. The upcoming IDA and AfDF replenishment negotiations present a timely opportunity to do so. Absent assertive and corrective action, the international community may be faced with the prospect of a HIPC IV agreement in the not too distant future.
\end{abstract}
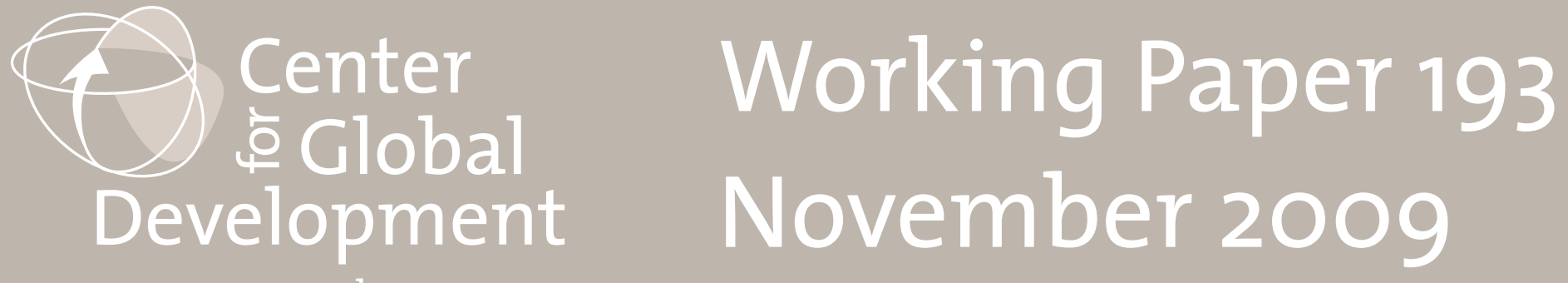


\title{
Will World Bank and IMF Lending Lead to HIPC IV? Debt Déjà-Vu All Over Again
}

\author{
Benjamin Leo
}

November 2009

Benjamin Leo formerly served as director for African affairs at the National Security Council and in a number of positions at the U.S. Department of Treasury. The author thanks the Government of Norway for support that allowed this work to be undertaken and Julia Barmeier for her tireless and professional work to create the new GDP projection dataset. I also thank Nancy Birdsall, Alan Gelb, Todd Moss, Steve Radelet, and several anonymous reviewers for input and comments on earlier drafts of this paper. The author is solely responsible for any errors in fact or judgment.

This paper was made possible by financial support from the Norwegian Ministry of Foreign Affairs.

Benjamin Leo. 2009. "The Impact of Microcredit on the Poor in Bangladesh: Revisiting the Evidence." CGD Working Paper 193. Washington, D.C.: Center for Global Development. http://www.cgdev.org/content/ publications/detail/1423285

Center for Global Development 1800 Massachusetts Ave., NW Washington, DC 20036

202.416 .4000

(f) 202.416 .4050

www.cgdev.org
The Center for Global Development is an independent, nonprofit policy research organization dedicated to reducing global poverty and inequality and to making globalization work for the poor. Use and dissemination of this Working Paper is encouraged; however, reproduced copies may not be used for commercial purposes. Further usage is permitted under the terms of the Creative Commons License.

The views expressed in this paper are those of the author and should not be attributed to the board of directors or funders of the Center for Global Development. 


\section{Foreword}

The debt burden of low-income countries has been one of the signature issues of the Center for Global Development. Our founding in 2001 was partly motivated by CGD chair Ed Scott's concern over the impact of debt on Latin American's poor, and our very first book was Nancy Birdsall and John Williamson's Delivering on Debt Relief: From IMF Gold to a New Aid Architecture. The Center has also been actively involved in debt policy toward countries initially outside of the HIPC initiative, including Liberia (later included in HIPC), Nigeria, and most recently Zimbabwe.

With Norwegian support, CGD is now turning its attention to the remaining debt issues after the Heavily Indebted Poor Country and Multilateral Debt Relief Initiatives (HIPC/MDRI). One of the principal concerns going forward is whether the lending policies of major creditors and donors could lead to yet another round of debt distress and perhaps require more debt relief in the future-an outcome HIPC/MDRI was supposed to prevent. This is likely to be a prominent issue on the minds of major creditors during the upcoming IDA-16 and ADF-12 replenishment negotiations.

As part of CGD's effort in this area, we are pleased to sponsor this working paper by Benjamin Leo, formerly of the U.S. Treasury and National Security Council and a key behind-the-scenes player in the inception and implementation of MDRI. Leo's paper looks at the issue of IFI lending and the potential risk of renewed debt re-accumulation by countries that have only recently completed HIPC/MDRI. His paper specifically examines the assumptions that go into lending decisions, especially the GDP growth projections and potential weaknesses in the debt sustainability framework, and raises serious concerns about the future. This will be a major contribution to the debate on the lending policies and use of grants for the poorest countries by the international financial institutions.

Todd J. Moss

Senior Fellow

Vice President for Corporate Affairs

Center for Global Development 
page intentionally blank 


\section{OVERVIEW}

In 2005, G-7 nations took the unprecedented step of forcing the World Bank, African Development Bank (AfDB), and International Monetary Fund (IMF) to cancel 100 percent of their outstanding debt claims on the world's poorest countries. In return, the G-7 and other shareholders committed to offset the foregone debt repayments on a dollar-for-dollar basis through increased contributions to these institutions over time. Later the Inter-American Development Bank followed suit and cancelled 100 percent of its claims on the five poorest countries in the western hemisphere. ${ }^{1}$ Through the Multilateral Debt Relief Initiative, the poorest and most heavily indebted countries ${ }^{2}$ stand to receive up to $\$ 60$ billion in debt relief over time. To date, 26 countries have already seen the cancellation of over $\$ 45$ billion of debt obligations. ${ }^{3}$ Moreover, the World Bank, AfDB, and IMF shareholders approved a new debt sustainability framework to govern future lending decisions and prevent the need for systemic debt relief in the future. ${ }^{4}$ The international community emerged from these agreements confident that the dragon of unsustainable debt finally had been slain.

Four years later, this paper examines whether poor countries' debt situations have stabilized or whether systemic risks of debt distress remain. In this context, I examine new lending volume levels and several interconnected issues that underpin the new debt sustainability framework failsafe, such as: (1) GDP and export growth performance; and (2) volatility in country performance levels. I find several striking and unsettling findings:

(1) World Bank and AfDB lending disbursement volumes remain high compared to predebt relief period standards. And, emergency IMF lending in response to the global economic crisis has compounded the situation.

(2) IMF and World Bank growth projections for HIPCs remain structurally overlyoptimistic compared to actual and historical performance. This phenomenon may have become worse since 2000.

(3) HIPCs continue to experience significant volatility in country performance measures - including numerous cases of deteriorated performance - which has a direct correlation with their ability to carry debt sustainably.

Collectively, these findings suggest that shareholders of the IMF, World Bank, and African Development Bank should take a fresh look at the issue of debt sustainability in low-income countries. In that examination, they should seriously consider the effectiveness of the IMF/World Bank debt sustainability framework as an instrument for preventing the resurgence of unsustainable debt levels and the need for yet another round of multilateral debt relief.

\footnotetext{
${ }^{1}$ Bolivia, Guyana, Haiti, Honduras, and Nicaragua.

${ }^{2}$ Heavily Indebted Poor Countries (HIPCs) include: Afghanistan, Benin, Bolivia, Burkina Faso, Burundi, Cameroon, Central African Republic, Chad, Comoros, Congo (Republic of), Cote Ivoire, Democratic Republic of Congo, Eritrea, Ethiopia, The Gambia, Ghana, Guinea, Guinea-Bissau, Guyana, Haiti, Honduras, Kyrgyz Republic, Liberia, Madagascar, Malawi, Mali, Mauritania, Mozambique, Nepal, Nicaragua, Niger, Rwanda, Sao Tome, Senegal, Sierra Leone, Somalia, Sudan, Tanzania, Togo, Uganda, and Zambia.

${ }^{3}$ Source: Heavily Indebted Poor Countries (HIPC) Initiative and Multilateral Debt Relief Initiative (MDRI) Status of Implementation, September 2009, page 39. Figure is represented in nominal terms.

${ }^{4}$ See World Bank and IMF (2006), Staff Guidance Note on the Application of the Joint Bank-Fund Debt Sustainability Framework for Low-Income Countries.
} 


\section{Historical ConteXt}

Over the last twenty-five years, the international community has pursued a series of measures to address debt burdens in low-income countries (see appendix I). Early actions focused on debt relief for official bilateral claims, initially via rescheduling, followed by increasing levels of debt stock reduction. During this period, the Paris Club $^{5}$ repeatedly reduced or rescheduled the debts of a number of countries, including good performers. Between 1976 and 2002, low-income countries restructured their Paris Club debt nearly 250 times, with twelve countries restructuring eight or more times. ${ }^{6}$

In 1996, IMF and World Bank shareholders agreed on the Heavily Indebted Poor Country Debt Initiative (HIPC). For the first time, loans from international financial institutions (IFIs) were included in broader debt stock reduction agreements. For their part, Paris Club creditors agreed to so-called "Lyon Terms," which provided debt stock reduction of up to 80 percent on eligible non-concessional bilateral claims. Due to slow implementation and continued debt risks, the international donor community agreed to the Enhanced HIPC Initiative in 1999. This initiative sought to provide faster and even deeper debt relief for poor countries. Paris Club creditors agreed to the "Cologne Terms," canceling up to 90 percent of eligible non-concessional bilateral obligations. Some G-7 creditors, including the United States, went as far as 100 percent debt reduction on both non-concessional and concessional loan obligations. The overriding objective was to reduce HIPCs' external debt ratios to or below a specific target level (debt/exports ratio of 150 percent).

Even as debt was relieved, HIPCs’ debt sustainability was eroded by even greater new official lending - primarily by IFIs. Between 1989 and 2003, new nominal lending to HIPCs more than doubled the amount of nominal debt relief provided ( $\$ 85$ billion versus $\$ 38$ billion). There were several reasons for excessive multilateral lending, including: (1) IFI institutional incentives; (2) defensive lending practices (i.e., rolling over preexisting claims to prevent default $)^{7}$; (3) a need to fill financing gaps created by sudden declines in commercial credit ${ }^{8}$; and (4) a poor credit culture within the borrowing countries themselves.

Against this backdrop, the G-7 finally took the conclusive and aggressive step in 2005 to implement the Multilateral Debt Relief Initiative and institute additional IFI reforms in an attempt to prevent unsustainable new lending. Additional use of grants rather than loans would protect countries from rebuilding unsustainable debt burdens, and a color-coded system would help guide the loans-grants mix for each country. The underlying concept was

\footnotetext{
${ }^{5}$ The Paris Club is an informal group of official bilateral creditors that seeks coordinated, sustainable solutions to the payment difficulties of debtor countries. Member countries include: Australia, Austria, Belgium, Canada, Denmark, Finland, France, Germany, Ireland, Italy, Japan, Netherlands, Norway, Russia, Spain, Sweden, Switzerland, United Kingdom, and the United States.

${ }^{6}$ See http://www.clubdeparis.org/en/ for details on country rescheduling treatments.

${ }^{7}$ Birdsall, Nancy, Stijn Claessens, and Ishac Diwan, "Policy Selectivity Foregone: Debt and Donor Behavior in Africa,” World Bank Economic Review, Volume 17(3), 2003, 409-435. Originally published as CGD Working Paper 17, October 2002.

${ }^{8}$ Easterly, William, "How did the heavily indebted poor countries become heavily indebted? Reviewing 2 decades of debt relief," World Development, Volume 30(10), October 2002, 1677-1696.
} 
to wipe the slate clean and proceed afresh with a prudent framework going forward. So, how are we doing?

\section{NEW LENDING VOLUMES}

Since 2000, the international community has mobilized tremendous amounts of new resources to finance development activities in low-income countries. This trend accelerated with the G-8 commitment at Gleneagles (2005) to double aid to Africa by 2010. While some countries are off-track to meet this commitment, such as France and Italy, overall aid levels have increased significantly.

The World Bank and AfDB have benefitted from this generosity. Donor replenishments for these institutions' concessional windows (International Development Association and African Development Fund) have experienced meteoric increases in recent years. For example, the IDA-15 and AfDF-11 replenishment agreements (2009-2011) will provide funding levels nearly 90 percent higher than during the 2000-2002 period. In dollar terms, these two organizations have roughly $\$ 23$ billion more in deployable funding than during the 2000-2002 period. If utilized effectively, this funding will have profound positive effects on the daily lives of people living in poor countries through increased investments in health, education, infrastructure, and private sector activities. At the same time, the sheer volume of financing can have destabilizing effects and can lead to renewed unsustainable debt burdens if provided in the form of new loans. The problem of debt in low-income countries has motivated the push by the United States since 2000, and to a lesser extent other donors, to press for reliance on grant funding.

Has the World Bank and AfDF moved to reduce lending volumes in recent years - especially given their risk of potentially creating yet another new external debt crisis in the very same countries? Despite a relative shift to grant funding, lending volumes have remained very high in absolute terms. This is especially striking following the progressively generous rounds of debt relief that cancelled billions of dollars in previous loans (Original HIPC, Enhanced HIPC, and MDRI). In the two years immediately following MDRI (2006 and 2007), the World Bank, AfDB, and IMF disbursed $\$ 7.8$ billion in new loans to HIPCs - the very same countries that received debt relief during that same period. ${ }^{9}$ This compares to $\$ 8.1$ billion in new loans immediately preceding MDRI (2004-2005). ${ }^{10}$ See figure 1 below. Hence, while the World Bank and AfDB have provided a greater percentage of funding in the form of grants, overall increases in assistance levels (as noted above) has led to similar lending volumes compared to the recent past.

\footnotetext{
${ }^{9}$ Source: OECD-DAC

${ }^{10}$ Ibid
} 
Figure 1 - IDA, AfDF, and IMF Lending Disbursements to HIPCs: 2000 - 2007

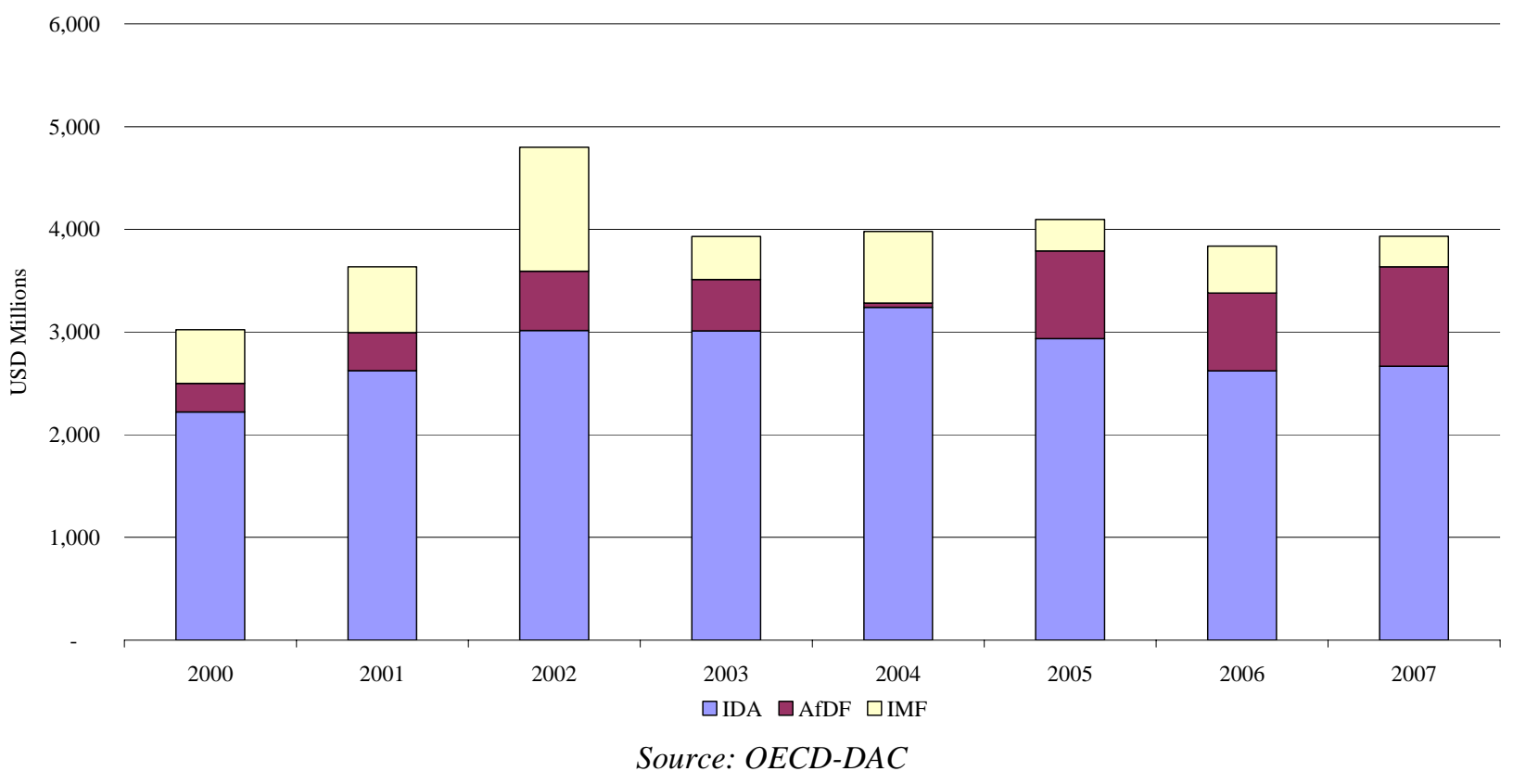

We also are witnessing a significant increase in IMF lending in response to the global economic crisis. As of May 2009, new IMF lending to African countries had exceeded $\$ 1.5$ billion (section IV deals with this issue in greater detail). In late July 2009, the IMF Board of Directors approved a series of measures that could mobilize up to \$17 billion in new loans to low-income countries through 2014. Of this, up to $\$ 8$ billion could be provided in the next two years. The IMF will introduce short-term interest teaser rates, which are designed to reduce the near-term fiscal impact. While this actual and projected lending will help boost international reserves and support structural adjustment policies in response to global shocks, they will further exacerbate the re-accumulation of new debts.

While new lending volumes to HIPCs overall remain high compared to pre-debt relief periods, we must recognize that dynamics will vary by country. Several HIPCs have maintained sustainable external indebtedness ratios following HIPC and MDRI relief, such as Mozambique. However, many HIPCs' debt ratios are projected to deteriorate substantially over the near- and medium-term due to decreased economic activity and increased borrowing volumes. A few examples include: Ethiopia, Malawi, Nicaragua, and Sierra Leone. ${ }^{11}$ While this paper examines external debt dynamics for HIPCs as an aggregated group, policymakers will need to take individual country circumstances into account as well.

\section{Growth Projections}

Historically, aggressive IMF and World Bank growth projections were used to justify ever increasing levels of new loans to poor countries. We examine recent projections for GDP and export growth in HIPCs to determine if systemic over-optimism has continued

\footnotetext{
${ }^{11}$ World Bank and IMF, Heavily Indebted Poor Countries (HIPC) Initiative and Multilateral Debt Relief Initiative (MDRI) - Status of Implementation, September 2009.
} 
unchecked or been addressed conclusively. Similar to previous studies (outlined below), we find further evidence of aggressive over-optimism across a number of different IMF data sources, such as IMF country reports (ex - Article IV reviews) and the IMF's World Economic Outlook database.

GDP Growth Projections: We have created a new GDP growth projection database for HIPCs covering the 1990-2007 period. ${ }^{12}$ All data is derived from official IMF reports, such as country reports and program reviews. This data and accompanying IMF staff analysis directly feeds into IFI lending decisions. Our findings suggest that GDP growth projections remain very optimistic compared to actual performance. On average, the IMF over-projects growth in HIPCs by greater than one percentage point annually (see figure 2 below). Given the growth volatility experienced by conflict countries, we also calculate the average growth projection performance for non-conflict and presumably more stable countries. Again, we find evidence of over-optimism - with growth projections outstripping performance by over 0.8 percentage points a year (see Appendix II for several country-specific illustrations). Outyear projections (two- and three-year forecast figures) exhibit similar over-optimism.

Figure 2 - IMF: Accuracy of GDP Growth Projections, 1990-2007 ${ }^{13}$

\begin{tabular}{lcccc} 
& \multicolumn{2}{c}{ All HIPCs } & \multicolumn{2}{c}{ w/o Conflict Countries } \\
Forecast Period & Average & Observations & Average & Observations \\
\hline 1 Year & 1.14 & 340 & 0.84 & 231 \\
2 Years & 1.62 & 274 & 1.00 & 187 \\
3 Years & 0.83 & 174 & 0.73 & 116
\end{tabular}

Source: IMF country reports and program review documents

Some may argue that the IFIs have become more aware and conscious of their contribution to debt accumulation following the introduction of the HIPC Initiative. However, GDP growth projections over a one-year time horizon remain more or less unchanged and threeyear projections have become even more optimistic (see figure 3 below).

Figure 3 - IMF: Accuracy of GDP Growth Projections, 2000-2007

\begin{tabular}{lcc} 
Forecast Period & HIPC Average & (w/o Conflict) \\
\hline 1 Year & 1.13 & 0.71 \\
2 Year & 0.80 & 0.82 \\
3 Years & 1.37 & 0.79 \\
\multicolumn{2}{l}{ Source: IMF country reports and program review documents }
\end{tabular}

With respect to the IMF's World Economic Outlook (WEO) forecasts ${ }^{14}$, we find similar over-projections of GDP growth performance for HIPCs of nearly 1 percentage point a year

\footnotetext{
12 The dataset covers all HIPCs with the exception of Somalia due to lack of IMF country data.

${ }^{13}$ Figures represent the average differential between projected and actual growth figures. Positive figures indicate projections that exceed actual performance. Projections cover one-, two-, and three-year time horizons.

${ }^{14}$ According to the IMF, there may be inconsistencies between WEO data and those included in country reports and performance reviews due to methodological differences and timing issues. Hence, we have examined both categories of data for illustration purposes.
} 
between 2001 and 2006 (see figure 4 below). At the same time, the IMF under-projected GDP growth for other low-income countries. Interestingly, the IMF's GDP growth projections were higher for HIPCs, on average, while this country group under-performed non-HIPCs in terms of actual GDP growth rates. This contrast raises stark questions about why IMF staff consistently produce rosy growth projections for HIPCs while underforecasting growth in other low-income countries. While outside the scope of this paper, this issue warrants further research.

Figure 4 - IMF WEO Database: Accuracy of 1-Year GDP Growth Projections

\begin{tabular}{lcrrrrrrr} 
Country Category & $\mathbf{2 0 0 1}$ & $\mathbf{2 0 0 2}$ & $\mathbf{2 0 0 3}$ & $\mathbf{2 0 0 4}$ & $\mathbf{2 0 0 5}$ & $\mathbf{2 0 0 6}$ & Average & Cum $\Delta$ \\
\hline All Low-Income Countries & -0.03 & -1.05 & 0.37 & 1.58 & -0.26 & 0.39 & 0.17 & 1.62 \\
Non-HIPCs Only & -0.91 & -3.49 & -0.61 & 0.55 & -1.12 & 1.16 & -0.74 & -1.32 \\
HIPCs Only & 0.59 & 1.38 & 0.92 & 2.17 & 0.24 & -0.06 & 0.87 & 3.36 \\
$\quad$ African HIPCs & 0.87 & 0.76 & 1.02 & 2.39 & 0.09 & -0.03 & 0.85 & 3.66 \\
\hline Difference (HIPCs vs Non-HIPCs) & $\mathbf{1 . 5 0}$ & $\mathbf{4 . 8 7}$ & $\mathbf{1 . 5 4}$ & $\mathbf{1 . 6 1}$ & $\mathbf{1 . 3 5}$ & $\mathbf{- 1 . 2 2}$ & $\mathbf{1 . 6 1}$ & $\mathbf{1 . 7 4}$ \\
$\quad$ (African HIPCs vs All) & 1.78 & 4.24 & 1.64 & 1.84 & 1.20 & -1.19 & 1.59 & 2.03
\end{tabular}

Negative figures indicate growth exceeded projections.

Source: IMF World Economic Outlook Database

Export Growth Projections: With respect to exports, many HIPCs' economies are concentrated in primary commodities and, therefore are highly vulnerable to volatility in world prices. In recent years, surging primary commodity prices contributed to strong export performance. Despite improved terms of trade, many countries still experienced a deterioration in their external indebtedness indicators during the same period. Given extreme export concentration in a small number of commodity sectors, a reversal in the price of specific commodities can cause a serious deterioration in low-income countries' external indebtedness indicators. This occurs both through the denominator side (exports) and the numerator side (lending, including emergency IMF assistance).

We are witnessing this fact in today's difficult global economic environment. The recent global downturn and related decline in commodity prices already has resulted in sharply reduced export levels and shocks for many HIPC economies. For example, following lower copper prices and export receipts, Zambia has been forced to borrow roughly \$170 million from the IMF to cover balance-of-payments needs. The IMF also has approved an additional \$160 million in PRGF loans for Zambia, which would bring the total amount to roughly \$330 million. ${ }^{15}$ As Zambia received MDRI relief in 2006, including nearly $\$ 600$ million from the IMF, it is alarming that it already is re-accumulating large, relatively expensive IMF loans.

In a similar fashion, the Democratic Republic of the Congo (DRC) has approached the IMF for emergency financial support following a sharp decline in commodity prices and export receipts. Increased government spending to support the war effort in eastern Congo also contributed to the country's deteriorated macroeconomic position. In the response, the IMF approved \$196 million in loans to the DRC in March 2009 through its Exogenous Shocks

\footnotetext{
${ }^{15}$ IMF Press Release No. 09/147
} 
Facility. ${ }^{16}$ This contrasts with the IMF’s ongoing commitment to provide roughly $\$ 320$ million in debt relief under the HIPC Initiative to the DRC. ${ }^{17}$ Put differently, the new IMF loans are canceling out the impact of debt relief before it has even been provided.

Given this structural vulnerability to trade shocks, have the IMF and World Bank taken steps to prudently project export growth performance? Unfortunately, numerous studies have found significant systemic optimism in export growth projections. In 2003, the World Bank itself acknowledged that export projections were significantly higher than actual historical performance - twice the levels from 1990-2000 and almost six times those from 19802000. ${ }^{18}$ Radelet and Chiang (2003) also compare staff projections for export and GDP growth and find similar results. ${ }^{19}$ A more recent World Bank study (2006) argues that accuracy has improved slightly since the 1980-2000 period, but upward biases continue to undermine the validity of the World Bank and IMF debt sustainability framework. ${ }^{20}$

Inter-Temporal Implications: Most striking, these GDP and export growth projections are for one or a few years - not the long-term growth projections currently used to justify new lending. IDA and AfDF have standard loan repayment periods of 40 and 50 years, respectively. As a result, it takes decades for respective countries to pay off new debt claims. Over this time horizon, systemically optimistic growth assumptions can have a massive impact on respective countries' projected external debt-to-GDP and debt-to-export levels. While margins of error in GDP growth projections may not seem large in the near-term, the long-term implications can be substantial.

The example of Guinea's projected and actual GDP performance between 1992 and 2007 provides an illustration of the stark cumulative implications (see Appendix III). Based upon the IMF's projected one-year GDP growth rates, Guinea’s economy would have reached \$6.5 billion by 2007. ${ }^{21}$ In reality, Guinea's actual GDP reached only $\$ 4.6$ billion - over 40 percent lower than projected. The IMF's two-year GDP growth rate projections would have put Guinea’s economy even larger (nearly \$7 billion) - or over 50 percent above actual achieved levels. These GDP growth projections would have suggested that Guinea was able to take on nearly $\$ 2$ billion in new loans without detrimentally impacting external indebtedness indicators. If donors acted upon these aggressive growth projections - as the World Bank/IMF debt sustainability framework dictates - Guinea's external debt situation would have been significantly worse. ${ }^{22}$

\footnotetext{
${ }^{16}$ IMF Press Release No. 09/74

${ }^{17}$ World Bank and IMF, Heavily Indebted Poor Countries (HIPC) Initiative and Multilateral Debt Relief Initiative (MDRI) - Status of Implementation, September 2008

${ }^{18}$ Gautam, Madhur, “Debt Relief for the Poorest: An OED Review of the HIPC Initiative,” World Bank Operations Evaluation Department, 2003.

${ }^{19}$ Radelet, Steve and Hanley Chiang, "Providing New Financing to Low-Income Countries with High Levels of Debt: Some Considerations,” Issue Paper on Debt Sustainability, HIPC Unit, World Bank, Washington DC, August 2003.

20 The World Bank Independent Evaluation Group, "Debt Relief for the Poorest: An Evaluation of the HIPC Initiative,” 2006.

${ }^{21}$ This figure is calculated by taking the cumulative and rolling impact of the IMF's one-year projected growth rates over time.

${ }^{22}$ Guinea's external indebtedness indicators already would have breached the World Bank/IMF debt sustainability framework thresholds during this time. Therefore, the World Bank (IDA) and African Development Bank (AfDF) would not have provided new concessional loans. Nonetheless, the example
} 


\section{Country Performance Volatility}

The new World Bank/IMF debt framework determines "sustainable" debt levels and lending decisions partly based upon the performance level of recipient governments. ${ }^{23}$ The underlying premise makes perfect sense; poorly governed countries are more likely to become debt-distressed at a lower external indebtedness level and better-performing countries can handle higher debt levels. Performance levels are based upon the World Bank's and African Development Bank's Country Policy and Institutional Assessments (CPIA), which evaluate countries according to 16 policy categories. ${ }^{24}$ Country scores range from 1 (low) to 6 (high). Under the World Bank/IMF framework:

- "Strong” performing countries (CPIA score > 3.75) have a sustainable debt carrying capacity ratio of 200 percent (NPV debt/exports);

- "Medium" performing countries $(3.25$ < CPIA score < 3.75) have a sustainable capacity of 150 percent; and

- "Poor" performing countries (CPIA score < 3.25) have a sustainable capacity of 100 percent.

In operational terms, IDA and AfDF compare these debt distress thresholds against current and projected debt ratios to determine risk classifications. ${ }^{25}$ In turn, these classifications determine whether a country should receive grants, loans, or a combination of the two (see figure 5 below).

\section{Figure 5 - World Bank/IMF Debt Sustainability Framework: Traffic Light System}

High-Risk (Debt Ratios Significantly Higher than Debt Distress Thresholds)

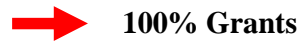

Medium-Risk (Debt Ratios Near Thresholds)

$50 \%$ Loans, $\mathbf{5 0} \%$ Gran

Low-Risk (Debt Ratios Well Below Thresholds)

$100 \%$ Loans

Volatility in country performance levels can have a significant impact on the risk of debt distress. By illustration, a "strong" performing country with a NPV debt/export ratio of 180 percent is considered sustainable under the debt sustainability framework. However, if that

illustrates the stark dangers of relying on aggressive and over-optimistic growth projections under the debt sustainability framework to determine the appropriate mix of concessional loans and grant financing.

${ }^{23}$ See Aart Kraay and Vikram Nehru (2004), "When Is External Debt Sustainable?” This empirical study finds that three factors explain a substantial percentage of cross-country and time-series variation in the incidence of debt distress: (1) overall debt burden; (2) the quality of country policies and institutions, and (3) the incidence of external shocks. The World Bank and IMF utilized these findings and associated confidence intervals to establish the debt sustainability framework for governing new lending decisions.

${ }^{24}$ See www.worldbank.org/ida for background information on the World Bank's Country Policy and Institutional Assessment (CPIA).

${ }^{25}$ While the IMF helped create the Low-Income Country Debt Sustainability Framework, it does not utilize it to govern its own lending decisions. 
country declines to a "medium" performance category, then it now can sustainably carry only a NPV debt/export ratio of 150 percent. Therefore, this deterioration in performance would immediately place the country at a statistically-significant probability of experiencing debt distress. Given this inherent threat, we examine the prevalence and persistence of deteriorated country performance over time.

The World Bank and AfDB utilize a three-year moving average of a given country's CPIA score to determine its appropriate debt distress risk classification. There is no empirical underpinning for the three-year moving average; it is designed solely to smooth out lending decisions for the World Bank and AfDB (i.e., to prevent grant allocation shares from fluctuating on an annual basis to reflect sustainable lending limits). In September 2009, the World Bank and IMF Boards approved additional actions to create further "inertia" in lending decisions. Despite these attempts to artificially smooth volatility in actual country performance; we find that governments still experience significant variance over time (see Appendix IV).

By illustration, the Gambia would have changed performance categories eight times during the 1979-2007 period. This includes a successive two-category decline between 1980 and 1982 (from "strong" to "poor"). Alternatively, Mauritania would have changed performance categories five times - including a successive two-category decline between 2004 and 2006 (from "strong" to "poor"). These examples are by no means isolated occurrences. Between 1979 and 2007, 29 HIPCs experienced a decline in their three-year moving average performance and debt distress category score levels. On average, each of these countries experienced an average of 3 declines over this period, with the decreased performance level continuing on average for 8 years. Between 1999 and 2007, 13 HIPCs experienced and/or continued a decline in their 3-year moving performance and debt distress category score. On average, the decreased performance level continued for 5 years.

The prevalence and persistence of performance declines over time again highlight the challenge of basing large volumes of new loans with 40- or 50-year amortization schedules on current performance levels that are likely to change. Some may argue that the World Bank and AfDB can modify lending levels in reaction to declined performance. Unfortunately, the current loan maturities simply are too long to facilitate timely adjustments. That is the equivalent of turning an aircraft carrier on a dime. Once the loans are made, they will remain on the books for decades to come (absent debt relief). Given this, the World Bank and AfDB should exercise significant caution in incorporating country performance levels into lending decisions.

Some may argue that HIPCs' performance levels have improved in recent years and are no longer vulnerable to the same level of historical volatility. Despite recent slippages, HIPCs' performance levels as a group has risen steadily since the late 1970s (see figure 6 below). However, the improvement has not been sufficiently large to force a widespread shift in debt sustainability performance categories. For example, 11 HIPCs' CPIA scores in 2007 would have produced a re-classification in their debt distress category compared to performance levels in 1999 (6 deteriorated and 5 improved). This clearly shows that volatility remains a pressing issue. 
Figure 6 - Average HIPC CPIA Score: 1979 - 2007

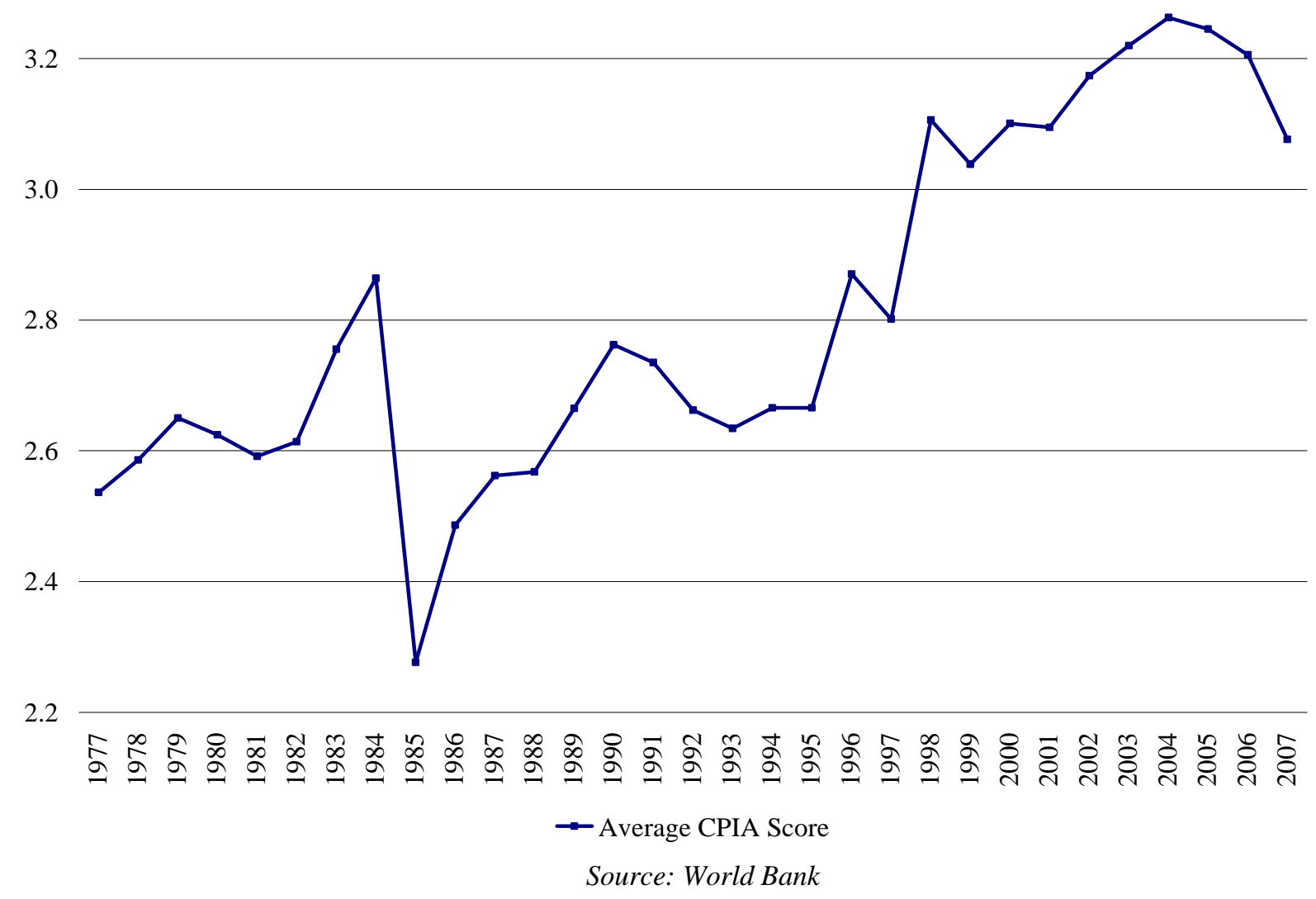

Moreover, several studies have found a statistical deviation between World Bank and African Development Bank CPIA country scores. Gelb, Ngo, and Ye (2004), estimate a standard deviation of 0.24 between each institution's respective performance scores for African countries. In light of these findings, they argue that a confidence interval of 0.5 would be reasonable. ${ }^{26}$ This interval is very large when compared to the World Bank/IMF framework performance category cutoffs (3.25 and 3.75). This problem is especially acute given the clustering of low-income country CPIA scores around these cutoffs. Our analysis suggests that 54 IDA-eligible countries' three-year average CPIA scores (out of 75 total) are within 0.5 points of the performance category cutoffs (see Figure 7 below). In other words, over 70 percent of IDA-eligible countries may be labeled incorrectly (either positively or negatively) under the World Bank/IMF debt sustainability framework.

\footnotetext{
${ }^{26}$ Gelb, Alan, Brian Ngo, and Xiao Ye (2004), "Implementing Performance-Based Aid in Africa: The Country Policy and Institutional Assessment.” World Bank Africa Region Working Paper 77.
} 
Figure 7 - CPIA Performance Clustering and Potential Labeling Errors

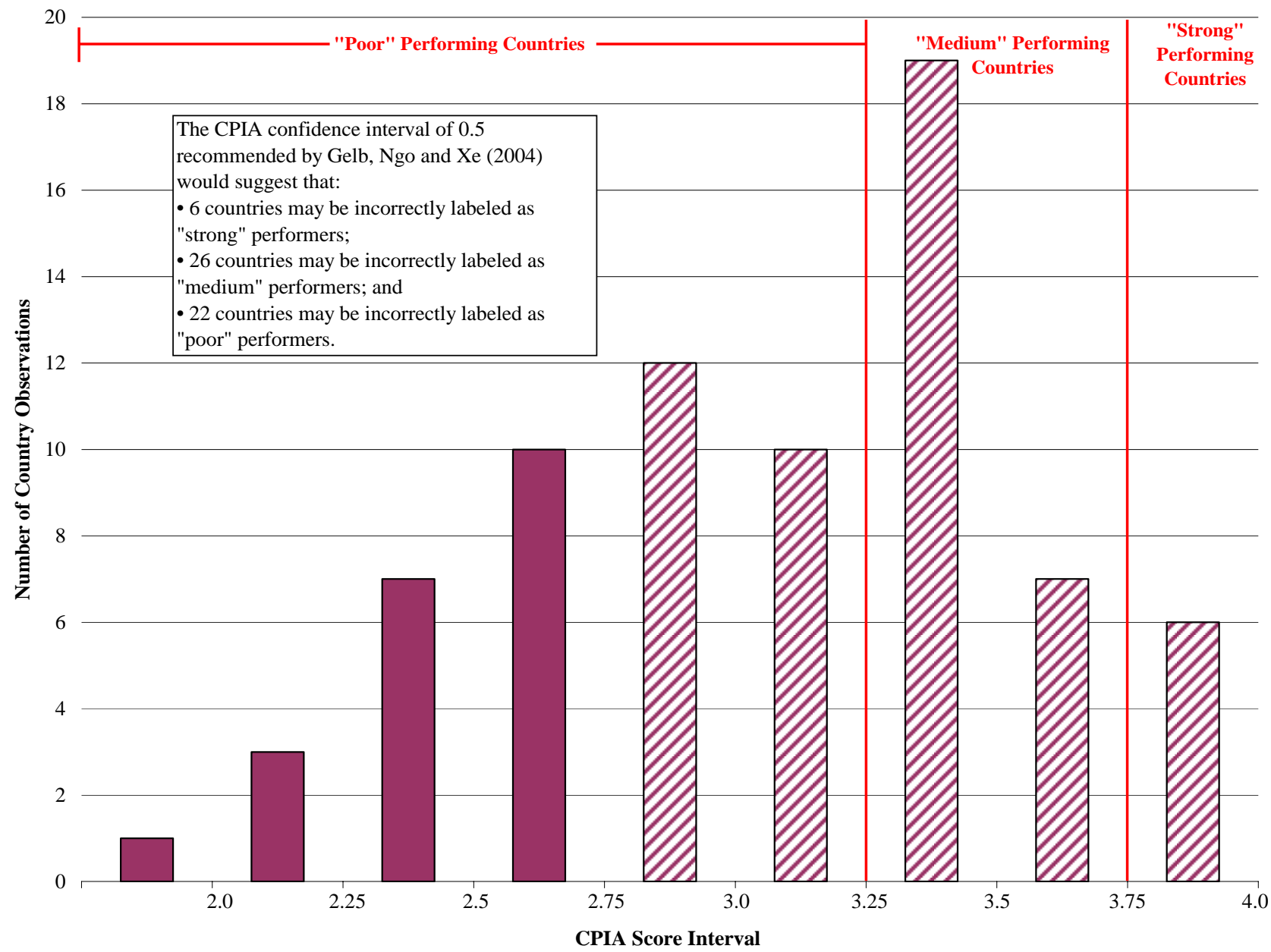

Source: World Bank CPIA data and author calculations

Kaufman and Kraay (2008) find an even larger divergence between specific sub-categories of World Bank and African Development Bank CPIA assessments. They find that the correlation between country scores on the CPIA transparency, accountability, and corruption sub-indicator is only $0.67 .{ }^{27}$ Undoubtedly, every performance indicator will be subject to measurement error. However, these findings argue for significant prudence concerning the application of the CPIA (or other performance indicators) to mechanistic lending frameworks.

\section{Policy Options}

Recognizing these structural and organizational limitations, how should IFI shareholders proceed? We recommend that they give careful consideration to a number of policy options during the upcoming IDA and AfDF replenishment negotiations, which presents a good opportunity to take corrective action. There are a number of possible policy options -

\footnotetext{
${ }^{27}$ Kaufmann, Daniel and Kraay, Aart (2008): Governance Indicators: Where Are We, Where Should We Be Going?
} 
ranging from a wholesale rejection of the debt sustainability framework to more targeted measures aimed at fixing the framework's shortcomings. A few options include:

(1) Fix the Debt Sustainability Framework: IFIs shareholders may wish to focus on implementing targeted corrections for the Debt Sustainability Framework's existing shortcomings. There are a number of possible options, such as:

(a) Incentivize Conservative Growth Projections: IFI management could consider ways to institutionalize more conservative GDP and export growth projections. One approach is to incorporate the accuracy of projections into relevant employees’ performance reviews and compensation packages.

(b) Static Repayment Capacity Guidelines: IDA and AfDF could determine appropriate lending terms based upon existing debt sustainability levels and not projected debt carrying capacity over time. This is similar to how private banks determine repayment capacity for mortgages and automotive loans. This approach would directly address the ongoing problem of overly-optimistic growth projections.

(c) Significant Cushions: IDA and AfDF could assume that overly-optimistic projections will continue and adjust the respective external debt ratios utilized to determine debt distress thresholds. By illustration, the debt sustainability framework's distress threshold for a “strong” performing country could be adjusted downward to allow a sustainable debt carrying capacity of 150 percent (NPV debt/exports) instead of 200 percent. This shift would ensure that a substantial buffer is structurally built into the framework, which would help offset systemic overly-optimistic growth projections or volatility in country performance levels.

(2) Jettison the Debt Sustainability Framework as a Grants vs. Loans Decision Mechanism: Given the continuing overly-optimistic growth projections and country governance volatility, IFI shareholders may wish to discard the debt sustainability framework entirely as the primary tool for determining appropriate lending terms. In its place, IFIs could utilize simple or sliding income thresholds for low-income countries. ${ }^{28}$ The InterAmerican Development Bank utilizes a sliding income scale to determine appropriate loan concessionality terms for many countries, including most low-income countries. ${ }^{29}$ Moreover, IDA and AfDF utilized income levels as one factor in determining grant assistance levels during the IDA-13 and AfDF-9 replenishment periods. ${ }^{30}$

\footnotetext{
${ }^{28}$ See Steve Radelet (2005), “Grants for the World's Poorest: How the World Bank Should Distribute Its Funds”, Center for Global Development. See also Nancy Birdsall \& Devesh Kapur (2005), "The Hardest Job in the World: Five Crucial Tasks for the New President of the World Bank," Center for Global Development. ${ }^{29}$ The IDB's Intermediate Financing Facility provides a sliding scale of concessionality terms for countries based upon income levels. This facility subsidizes regular Ordinary Capital (OC) lending terms to achieve the targeted concessionality level. Several low-income countries are eligible for facility subsidies, including: Bolivia, Guyana, Honduras, and Nicaragua.

${ }^{30}$ If countries' GDP per capita was less than $\$ 360$, then they were eligible to receive up to 40 percent of total replenishment assistance envelopes in the form of grants.
} 


\section{CONCLUSION}

Recent evidence suggests that the World Bank, AfDB, and IMF have not taken aggressive action to reform their growth projections and lending decisions. The new debt sustainability framework clearly represents a substantial step in the right direction. However, the framework itself is only as good as its analytical inputs. Without conservative and accurate GDP and export growth projections, the framework will not prevent future instances of HIPC debt distress. Equally important, the prevalence of country performance volatility necessitates a significant buffer in external indebtedness ratios compared to sustainable levels. This will help to prevent future instances of debt distress in the event that HIPCs experience declines in performance levels. Moreover, the World Bank and AfDB clearly need to utilize grant financing more extensively. Given that nearly every donor provides contributions to these institutions on a grant-basis; it is not unreasonable to expect that they would provide the same terms to the world's poorest countries. If not, and if the World Bank and IMF do not rein in their systemic over-optimism, then the international community could be looking at a HIPC IV agreement in the not too distant future. In the meantime, donors will be on the hook to provide tens of billions of dollars in additional contributions to the World Bank, AfDB, and IMF to cover the last round of debt relief. 


\section{Appendix I}

\section{Low-Income Countries: Chronology of Debt Treatments}

The following chronology shows the increasingly generous debt treatments offered over time:

- From the 1960s through the mid-1980s, Paris Club debt relief for low-income countries was limited to rescheduling of claims.

- In 1987, the Group of Seven countries (G-7) called for interest rate relief on low-income countries' debt, creating the "Venice terms."

- In 1988, the Paris Club agreed on partial debt reduction (33 percent) and more generous rescheduling terms, creating "Toronto terms."

- In 1991, the Paris Club applied "Enhanced Toronto Terms," which deepened the level of debt reduction to 50 percent.

- In 1994, the Paris Club announced “Naples Terms” with even deeper levels of debt reduction (67 percent) and more generous rescheduling terms on remaining debt.

- In 1996, members of the IMF and World Bank agreed on the Heavily Indebted Poor Country Debt Initiative (HIPC). For the first time IFI credits were reduced. Paris Club creditors agreed to "Lyon Terms," which increased debt reduction on eligible nonconcessional bilateral claims to 80 percent.

- In 1999, the international donor community agreed to the Enhanced HIPC Initiative, providing faster and even deeper debt relief, for more countries. Paris Club creditors agreed to the "Cologne Terms," canceling up to 90 percent of eligible non-concessional bilateral obligations. Some G-7 creditors, including the United States, went as far as 100 percent debt reduction.

- In 2006, the World Bank, African Development Bank, and International Monetary Fund agreed to provide 100 percent debt stock reduction for qualifying HIPCs. The InterAmerican Development Bank agreed to equivalent treatment soon thereafter. 
IMF Growth Projections Versus Actual Performance: Select Countries

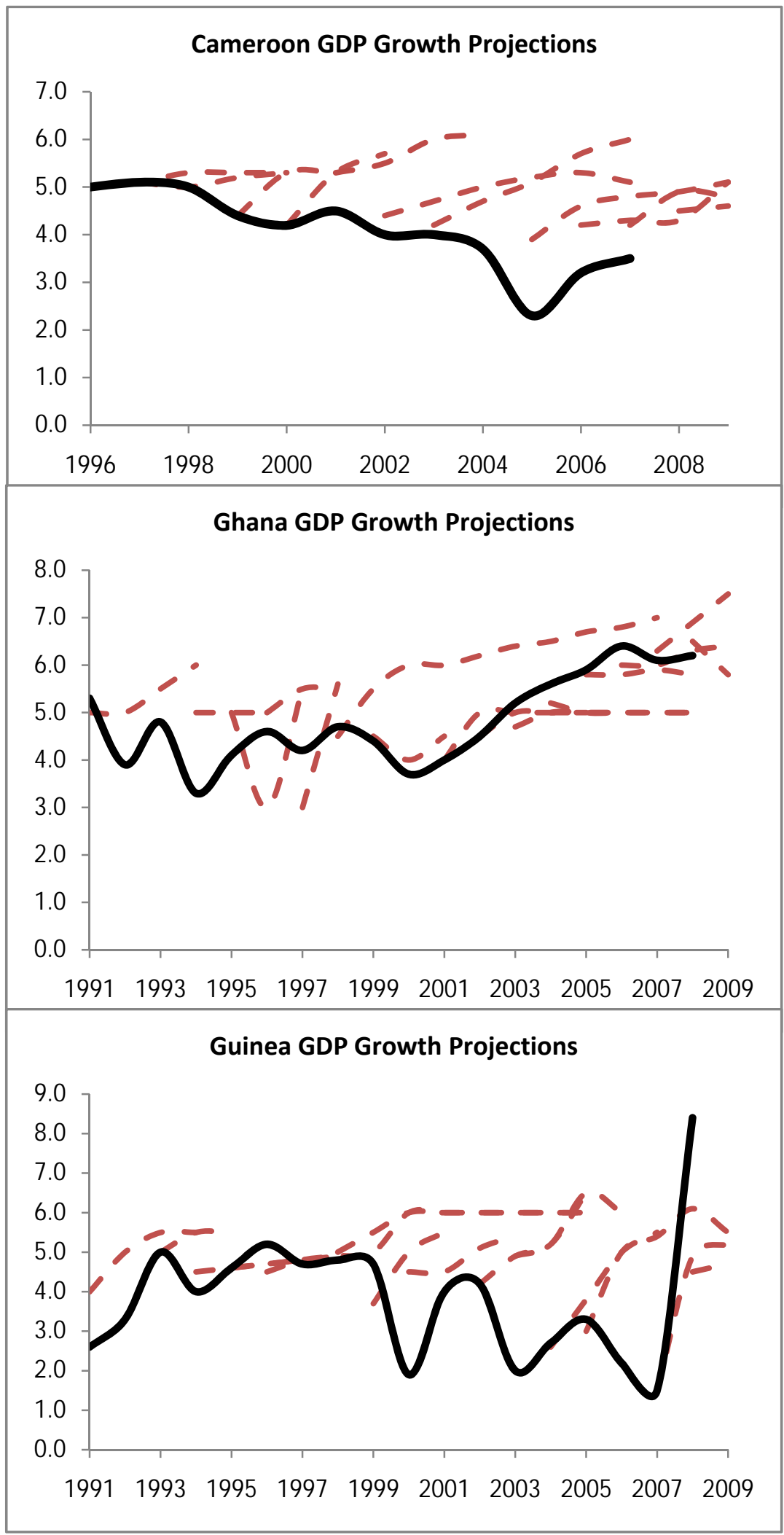

- GDP annual \% change

- IMF projected GDP growth 


\section{Appendix III}

\section{Guinea: IMF GDP Growth Projections Versus Actual Performance, 1992-2007}

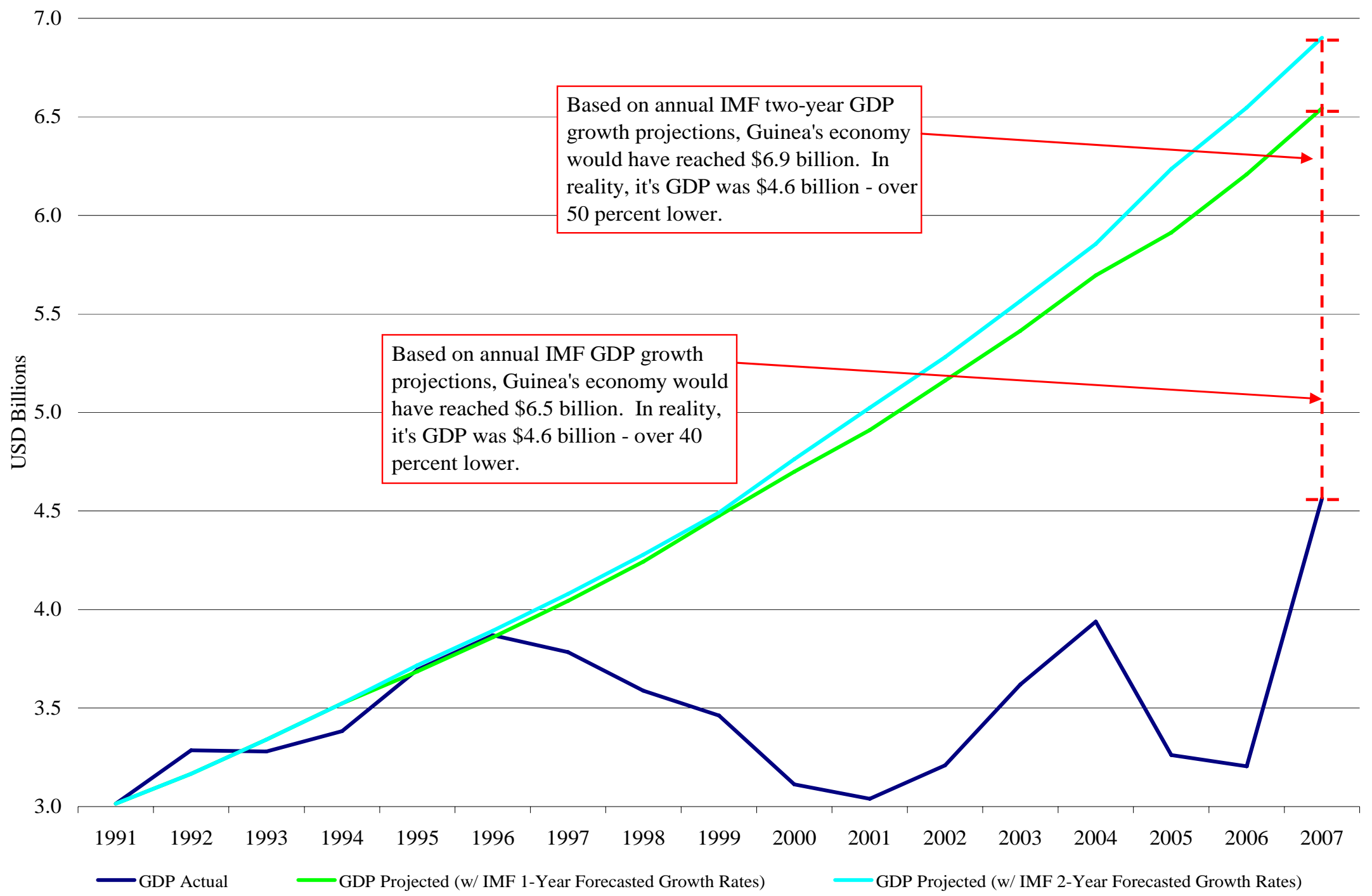

Source: IMF Country Documents, WB World Development Indicators 


\section{CPIA Volatility and Debt Distress Risk: Selected HIPCs}

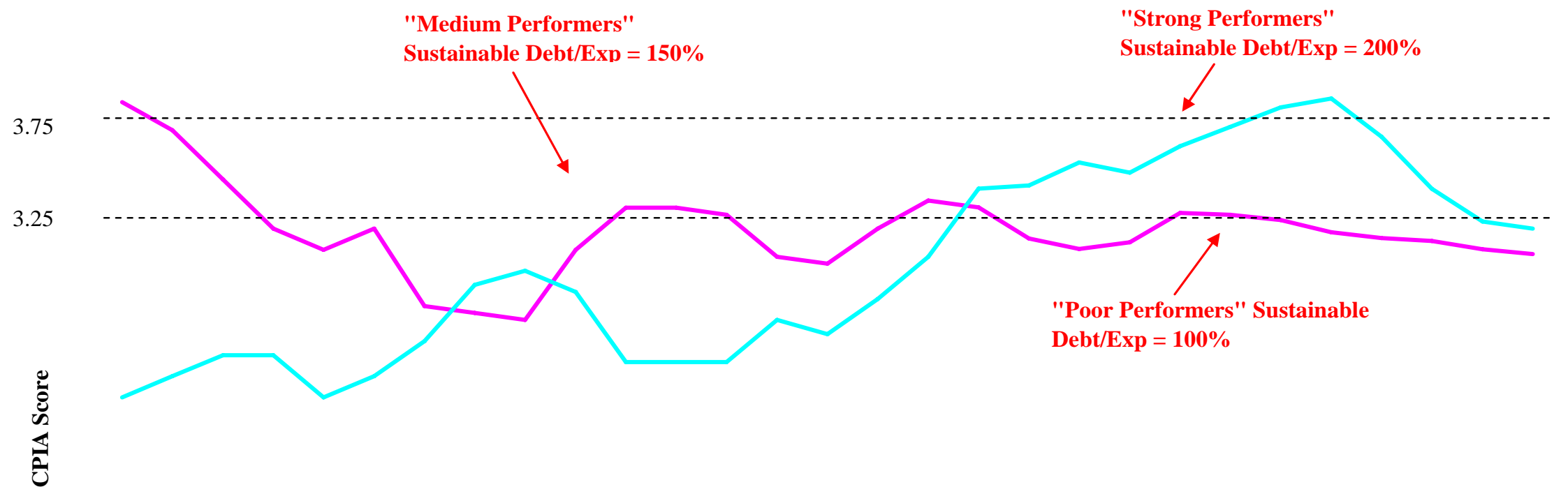

Key Findings:
• Based on its CPIA scores, the Gambia would have
changed performance categories eight times during the
1979-2007 period. This includes a successive two-
category decline between 1980-1982 (from "strong" to
"poor").
- Mauritania would have changed performance categories
five times. This includes a successive two-category
decline between 2004-2006 (from "strong" to "poor").

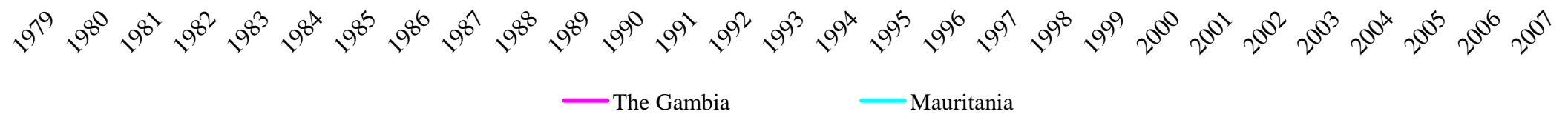

